\title{
NECESSITA AQUELA PROVÍNCIA. NÃO SÓ DE GOVERNADOR. MAS DE CORONEL DE DRAGÖES: OS COMANDANTES DE FRONTEIRA PORTUGUESES E O GOVERNO DA CAPITANIA DO RIO GRANDE DE SÃO PEDRO. SÉCULO XVIII
}

ADRIANO COMISSOLI

UNIVERSIDADE FEDERAL DE SANTA MARIA

SANTA MARIA - RIO GRANDE DO SUL - BRASIL

LEANDRO ROSA DE OLIVEIRA**

UNIVERSIDADE FEDERAL DO RIO GRANDE DO SUL PORTO ALEGRE - RIO GRANDE DO SUL - BRASIL
RESUMO

\section{ASTRACT}

$\mathrm{O}$ artigo aborda o cargo denominado Comandante de Fronteira, que operou na capitania do Rio Grande de São Pedro nos séculos XVIII e XIX. Através da análise de suas funções e do grau de interferência sobre a sociedade, discute estratégias de governo e de territorialização no império português durante a segunda metade do Setecentos. Sendo um cargo não identificado para outras realidades do império luso, procurase inserir os Comandantes de Fronteira em tradições ibéricas de governo civil e militar. Com este objetivo, discute as ordens e instruções emitidas pelo governador da capitania a fim de compreender como se estabelecia o governo e a administração territorial.

Palavras-chave: Fronteira; Governo; Território.

The paper approaches the role known as Borderland Commander (Comandante de Fronteira), which operated in the captaincy of Rio Grande de São Pedro during the 18th and 19th centuries. Analysing his duties and the degree in which he could interfere on the society the paper discusses strategies of government and territorialization for the Portuguese empire during the second half of the 1700's. As an office non-identified for other spatial realities on Portuguese empire it searches to link the Borderland Commanders with Iberian traditions for civil and military government. For this purpose, the paper discusses the orders and instructions sent by the governor of the captaincy seeking to understand how the government and territorial administration were stablished.

Keywords: Borderland; Government; Territory.

\footnotetext{
Doutor em História Social (UFRJ) e Professor Adjunto do Departamento de História da Universidade Federal de Santa Maria (UFSM). Sua pesquisa sobre espionagem teve aportes da FAPERGS e CNPQ. E-mail: adrianocomissoli@hotmail.com.

Mestre em História (PUCRS). Doutorando no Programa de Pós-Graduação em História da Universidade Federal do Rio Grande do Sul (UFRGS), com bolsa de fomento CAPES. E-mail: leandrodeoliveira@msn.com.
} 
No ano de 1769 o vice-rei do Estado do Brasil, Conde de Azambuja (1767-1769), teve diante de si a tarefa de nomear novo governador para a capitania do Rio Grande de São Pedro, então em situação bastante delicada. Seis anos antes, uma força de 1.000 espanhóis tomara os fortes portugueses de Santa Teresa e São Miguel, o que permitiu capturar sem dificuldades a vila do Rio Grande de São Pedro. O ataque resultou na debandada de grande parte da população, incluindo o governador Tomás Luís Osório, o provedor da fazenda, o vigário e os oficiais da Câmara, os quais se refugiaram no povoado de Viamão a fim de restabelecer o funcionamento do governo. O episódio foi visto com muito maus olhos pelo rei Dom José I e seu secretário de Estado, Conde de Oeiras, já assoberbados pelos efeitos negativos da Guerra dos Sete Anos sobre Portugal (1756-1763).

A vila de Rio Grande era compreendida como parte importante dos planos bragantinos para o extremo sul. Sua posição geográfica permitia o controle do acesso oceânico à lagoa do Patos, e a vila também se comunicava comercialmente e apoiava militarmente a praça da Colônia do Sacramento, dedicada ao comércio lícito e ilícito com os espanhóis de Buenos Aires. Em síntese, a perda de Rio Grande alterara o equilíbrio tenso na região em desfavor de Dom José I e seus súditos. A situação se tornou mais singular na medida em que a Paz de Paris (1763) determinou o fim das hostilidades entre os reinos ibéricos. Não obstante, no sul da América os confrontos seguiram um ritmo autônomo, de modo que em 1767 o coronel José Custódio de Sá e Faria, novo governador da capitania do Rio Grande (1764-1769), intentou retomar a vila. Seu fracasso aumentou a pressão sobre os portugueses, que passaram a temer novos avanços hispânicos e a buscar homens capazes de atuar simultaneamente no governo civil e militar da região. Este era o delicado desafio que o Conde de Azambuja havia de enfrentar, percebendo ao mesmo tempo que muitos dos oficiais militares de que dispunha não podiam ser realocados. Diante do cenário considerou que

[...] necessita[va] aquela Província, não só de Governador, mas de Coronel de Dragões, o que me parece poderá exercer a mesma pessoa, com utilidade do Serviço de S. Majestade, por serem os Dragões a principal defesa daquela 
Fronteira. José Marcelino entendo ser capaz, [...] mas o tempo é que nos há de dar a inteira certeza disso. ${ }^{1}$

E assim incumbiu o governo da capitania meridional e o comando de sua principal tropa a José Marcelino de Figueiredo, em conjuntura acentuadamente difícil. ${ }^{2}$

Foi durante o governo de Figueiredo que passou a existir na capitania um cargo específico: o de Comandante de Fronteira. ${ }^{3}$ Tal posto não é localizado em guias documentais voltados à administração do império português. As buscas junto aos repositórios digitais $O$ governo dos outros; e-Dicionário da terra e do território no Império Português e do projeto Memória da Administração Pública Brasileira não trazem resultados para a expressão. Igualmente, a obra de Graça Salgado, Fiscais e Meirinhos, não a arrola entre os inúmeros cargos abordados. Mesmo no trabalho de Márcia Miranda, voltado à administração do Rio Grande de São Pedro, os Comandantes de Fronteira estão ausentes. ${ }^{4}$ Portanto, partindo de consultas documentais, identificamos que a designação Comandante de Fronteira surgiu na década de 1760, sendo desenvolvida a partir da vivência do coronel Marcelino de Figueiredo na região, a qual evidenciou necessidades da organização militar e civil. Nesse sentido, e no intuito de compreender o surgimento desse posto, o objetivo do presente artigo é perceber uma política de territorialização desenvolvida por parte do Império português no século XVIII durante o governo de Marcelino de Figueiredo. Para tanto, a argumentação desenvolve-se em torno de duas perguntas principais: em que consistia o cargo de Comandante de Fronteira? Qual seu papel na organização do governo da capitania de São Pedro e de seus territórios? Para respondêlas, discorreremos inicialmente sobre o surgimento desse cargo.

\footnotetext{
1 ARQUIVO NACIONAL. Códice 69, Vice-reinado. Registro de correspondência do vice-reinado para a Corte. Conde de Azambuja a Francisco Xavier de Mendonça Furtado, 09 de março de 1769. fl. 36v-38.

${ }^{2}$ Uma análise recente do governo de José Marcelino, acompanhada de dados biográficos e da questão de sua identidade secreta pode ser vista em KÜHN, Fábio. Um governador em apuros. A trajetória administrativa de José Marcelino de Figueiredo (Rio Grande de São Pedro, 17691780). In. DORE, Andréa. Temas setecentistas: governos e populaçoes no Império português. Curitiba: UFPR, 2008, p. 169-180.

${ }^{3}$ Optamos por redigir o posto conforme a grafia da época, iniciando suas palavras em maiúsculas, dado que essa redação aponta para a distinção do posto e, na mesma medida, funde-se com o nome de seus ocupantes.

${ }^{4}$ O governo dos outros ICS (ul.pt), consultado em 01/08/2021. e-Dicionário da terra do território no Império Português da Terra e do Território no Império Português «e-Dicionário (edittip.net), consultado em 10/10/2021. Memória da Administração Pública Brasileira Página inicial (an.gov.br), consultado em 10/10/2021. SALGADO, Graça (coord.). Fiscais e Meirinhos, A Administração no Brasil colonial. Rio de Janeiro: Nova Fronteira, 1986. MIRANDA, Márcia Eckert. Continente de São Pedro: a administração pública no período colonial. Porto Alegre: Assembléia Legislativa do Estado do RS/Ministério Público do Estado do RS/CORAG, 2000.
} 


\section{“SEM PODER ACUDIR AS DUAS FRONTEIRAS": DAS NECESSIDADES DE UMA CAPITANIA EM GUERRA AOS COMANDANTES DE FRONTEIRA}

Enquanto oficial militar, José Marcelino de Figueiredo já atuava no extremo sul antes da nomeação a governador, tendo sido responsável pelo acampamento de São Caetano, posição a norte do canal da lagoa dos Patos, onde as forças militares portuguesas se reagruparam após a perda da vila de Rio Grande em 1763. A experiência de Marcelino no comando da tropa ali estacionada seria reivindicada a partir de sua ascensão a governador. Não obstante, o fato do Rio Grande ter se tornado capitania subalterna ao Rio de Janeiro em 1760 e a perda de área em 1763 expuseram lacunas sobre as prerrogativas de seu governo, as quais foram colocadas à prova enquanto Marcelino exerceu o cargo. As dúvidas só fizeram aumentar a partir da presença do tenente-general João Henrique de Böhn desde fins de 1774, enquanto comandante-em-chefe das forças lusas destinadas a retomar Rio Grande.

A subordinação ao vice-rei e a partilha da autoridade militar com Böhn, além de atritos com os vereadores, resguardados na freguesia de Viamão, geraram perplexidade a José Marcelino. Ao longo de seu governo, entre 1769 e 1780, esse governador experimentou flutuações em sua autoridade e nas tarefas que lhe cabiam realizar. No tocante ao governo militar, suas prerrogativas foram limitadas pela chegada de Böhn, em 1774, o qual ostentava patente superior e ordens expressas do vice-rei para assumir o comando da ação de guerra. Dessa forma, José Marcelino se restringia ao governo "econômico e civil"”, atuando somente enquanto governador. Em dado momento, já tendo sido promovido a brigadeiro, foi destinado por Böhn ao Comando da Fronteira do Rio Pardo, o que entendeu ser uma humilhação, dado que até pouco tempo governava a capitania inteira. Essa situação peculiar, imprevista na nomeação do governador ou em qualquer instrução, disparara dúvidas. Em carta ao tenentegeneral ele apresentava incertezas e desconforto:

\footnotetext{
${ }^{5}$ Ao instruir o tenente-general João Henrique de Böhn quando este se encaminhava para a capitania de São Pedro do Rio Grande, o vice-rei Marquês de Lavradio explicitou àquele oficial as suas atribuições enquanto comandante do exército, "para se evitarem todas as dúvidas de jurisdições". Nessa posição, Böhn poderia passar ordens ao governador, o qual ficava subordinado àquele oficial nos assuntos militares. Em virtude disso, explicita o vice-rei: "Ao governador toca o econômico e civil do Continente, e pelo que pertence a Administração da Real Fazenda, com as mais pessoas que para isso lhe forem nomeadas.” BIBLIOTECA NACIONAL. Coleção Martins, 13, 04, 02. Correspondência do Marquês de Lavradio com o Marechal João Henrique de Böhn. 1774-1775. 3 de dezembro de 1774, fl. 46-52.
} 


\begin{abstract}
V. Ex. ${ }^{\text {a }}$ sabe que depois de sua chegada neste Continente eu me abstive sempre de dar ordens para essas partes, ainda no Econômico, e Civil, principalmente depois que não soube [que ou ?] era o Tenente de Governador, ou antes o Comandante da Fronteira, mas que contudo tenho trabalhado incessante tanto no governo e defensa desta Fronteira debaixo das suas ordens, como para a subsistência das tropas de todo o Exército, o sossego destes Povos, e para agradar e servir a V. Ex. ${ }^{a}$ a que protesto continuar pois eu confesso ser de V. Ex. ${ }^{a}$ o mais obrigado e fiel Criado. $^{6}$
\end{abstract}

A menção ao tenente de governador remete à figura dos tenientes de gobernador, comuns nas possessões espanholas da América. Os tenientes eram nomeados pelos governadores e a eles subordinados para atuar em cidades (pueblos) distantes da sede de governo. Eram selecionados dentre os homens de projeção social e econômica de uma cidade, realizando uma convergência entre poder local e central. De fato, não era incomum que o teniente acumulasse o cargo de alcaide mayor, exercendo atividades de Justiça com respaldo do governador nomeado pelo rei. Não obstante, a concentração de autoridades em um mesmo indivíduo terminava por fortalecer sua posição de liderança local, a qual permitia opor-se a projetos oriundos dos centros de decisão espanhóis. ${ }^{7}$

$\mathrm{O}$ teniente de gobernador aproximava-se dos mestres de campo das possessões portuguesas, lideranças locais que - independentemente de suas patentes militares - eram reconhecidas enquanto parceiros fundamentais na organização das comunidades. Exerciam atividades policiais, apuravam crimes, julgavam disputas e, sobretudo, organizavam as forças militares não-regulares, especialmente os terços auxiliares, surgidos na conjuntura da aclamação dos Bragança ao trono português. ${ }^{8}$ A aposta nos mestres de campo procurava sanar limitações tanto das tropas de primeira linha quanto das ordenanças. Contudo, trabalhava-se com a mesma ambiguidade dos tenientes, pois ao conferir "uma muy honrosa" patente militar

\footnotetext{
${ }^{6}$ BIBLIOTECA NACIONAL. Coleção Martins, 13, 06, 06. Correspondência de José Marcelino de Figueiredo com o General João Henriques Bohm. 1774-1776, fl. 444-445.

${ }^{7}$ CORI, Gabriel H. El Teniente de Gobernador Joaquín Maciel y la administración de las Temporalidades. Santa Fe, 1776-1771. Historia Regional, Sección Historia. ISP N ${ }^{\circ} 3$, Año XIX, No 24, 2006, p. 133-150. QUINTERO, Gilberto R. Gobernadores y tenientes de gobernador en la província de Venezuela. De los Welser a Juan de Villegas (1528-1553). Revista Mañongo, nº17, 2001 pp. 289-300. DOUGNAC RODRÍGUEZ, Antonio. Gobierno, justicia, guerra y hacienda. Autoridades radicadas em Indias. In: Manual de História del derecho indiano. México: McGraw-Hill, 1998.

${ }^{8}$ DIAS, Gabriela Duque. “Uma muy honrosa” patente militar: os mestres de campo nas Minas Setecentistas (1709-1777). Juiz de Fora: PPGHUFJF, dissertação de mestrado, 2013. COSTA, Fernando Dores. Insubmissão. Lisboa: Imprensa de Ciências Sociais, 2010 , p. 159-164.
} 
a potentados locais fortalecia-se suas autoridades sem subordiná-las. Manuel Nunes Vianna, líder do grupo emboaba que disputou a região aurífera com os paulistas, demonstrou o quão paradoxal a atuação dos mestres poderia tornar-se. Já ostentando a patente, teve frequentes conflitos com o governador de Minas, ao qual, em teoria, estaria subordinado. A capacidade e autoridade de Vianna de mobilizar homens para luta, fosse ela a conquista diante dos indígenas, fosse para a rebelião, tornavam-no um aliado tanto quanto uma ameaça. A Coroa não ignorou esta situação e por isso foi reduzindo a nomeação de mestres de campo para Minas Gerais ao longo século XVIII. Dos 53 mestres nomeados na centúria, 41 (92,5\%) receberam a patente antes de $1740 .{ }^{9}$

O abandono da nomeação de novos mestres de campo esteve contido no governo de Gomes Freire de Andrade no Rio de Janeiro (1733-1763), o qual incluiu Minas Gerais a partir de 1735. O mesmo governador esteve à frente da expedição de demarcação do Tratado de Madri, que o obrigou a uma estadia de alguns anos no Rio Grande de São Pedro. É factível que durante o século XVIII a experiência em nomear lideranças locais tenha chegado ao seu limite, no entendimento das Coroas ibéricas, as quais desistiram de mestres e de tenientes em favor de oficiais das tropas regulares. O trabalho de Mônica Ribeiro respalda essa interpretação, pois advoga a aproximação entre as práticas de governo de Gomes Freire e as ideias que configuravam a razão de Estado portuguesa e sua defesa dos interesses da dinastia reinante frente a exigências dos súditos. ${ }^{10}$ Portanto, o desgaste da Coroa em confrontar-se com lideranças que ela própria havia apoiado - algo que pode ser evidenciado nos muitos motins em Minas Gerais na primeira metade do setecentos - conduziu à substituiç̧ão da política para organizar os territórios das possessões lusas no continente americano ${ }^{11}$. De fato, para o Rio Grande de São Pedro não localizamos a nomeação de mestres de campo, dado que a penetração lusitana e a organização do governo da capitania se deram predominantemente na segunda metade do XVIII.

\footnotetext{
${ }^{9}$ DIAS, 2010 , p. 57.

${ }^{10}$ RIBEIRO, Mônica. "Razão de Estado” e Administração: Gomes Freire de Andrada no Rio de Janeiro, 1733-1748. Niterói: Dissertação de Mestrado, PPG em História da Universidade Federal Fluminense, 2006.

${ }^{11}$ FIGUEIREDO, Luciano Raposo de Almeida. O Império em Apuros: Notas para o Estudo das Alterações Ultramarinas e das Práticas Políticas no Império Colonial Português Séculos XVII e XVIII. In. FURTADO, Júnia Ferreira. Diálogos Oceânicos. Belo Horizonte: Editora UFMG, 2001.
} 
Todavia, a alteração deu-se enquanto uma experiência coletiva, isto é, o abandono de certas práticas em favor de novas sem que estivessem previstas em qualquer código ou regramento. Dessa forma, explica-se a confusão de José Marcelino de Figueiredo: qual a função que deveria realizar? Quais incumbências lhe cabiam? E como poderia atendê-las tendo em vista a amplitude do território sul rio-grandense?

É preciso considerar que desde 1750 o extremo sul da América se tornara um espaço amplamente disputado entre os ibéricos, o que fez os coevos utilizarem a expressão fronteira e sua retórica para designar algumas das áreas dessa parcela do continente. $\mathrm{O}$ vocábulo fronteira podia ser empregado com diferentes significados. Por vezes referia-se ao conjunto das possessões portuguesas vizinhas aos territórios espanhóis; por vezes referia-se a partes específicas das posses lusas, nas quais o contato com os confinantes era particularmente próximo. É seguro afirmar que a palavra fronteira era dotada de forte polissemia no século XVIII, referindo-se a uma área, mas também a uma situação social.

A polissemia também englobava acepções próximas à ideia de dinâmica, denotando um movimento. Os hispânicos compreendiam algumas parcelas de seus domínios americanos através da "concepción de la frontera como confin: zona hasta donde llegaba el império del rey y desde la cual aún continuaba el avance de conquista y colonización territorial"12. Essa ideia de matriz medieval influenciou a caracterização das fronteiras nas possessões castelhanas na América. Tal concepção certamente integrava também o arcabouço cultural luso, tendo em vista o lastro comum de categorias de compreensão e organização territorial compartilhado pelos ibéricos ${ }^{13}$. Ela se aproxima da definição presente no "Elucidário das palavras, termos e frases que em Portugal antigamente se usaram e que hoje regularmente se ignoram”, em que não diz respeito a uma raia divisória ou a um limite preciso, mas ao próprio movimento, a "ir em fronteira" com objetivos exploratórios e de conquista. ${ }^{14}$ Ao se vincular ao movimento de expansão, à guerra e à conquista, tais acepções caracterizam a fronteira fortemente enquanto dinâmica, com estímulo ao avanço por áreas adjacentes. Contudo, a ideia de fronteira enquanto

\footnotetext{
${ }^{12}$ ARRIAGA RODRÍGUEZ, Juan Carlos. El largo proceso histórico de partición territorial: las fronteras em América Latina y el Caribe, siglos XVI al XXI. México: Bonilla Artigas Editores/Universidad de Quintana Roo, 2012, p. 30.

${ }^{13}$ CARDIM, Pedro; HESPANHA, António Manuel. A estrutura territorial das monarquias ibéricas. In: XAVIER, Ângela Barreto et al. (Org.). Monarquias ibéricas em perspectiva comparada. Lisboa: ICS - Imprensa de Ciências Sociais, 2018.

${ }^{14}$ Os dois volumes do "Elucidário..." foram publicados em 1798 e 1799, por Joaquim de Santa Rosa de Viterbo. Cf. BICALHO, Maria Fernanda Baptista. Sertão de Estrelas. A delimitação das latitudes e das fronteiras na América Portuguesa. Varia História, Belo Horizonte, v. 21, p. 73$85,1999$.
} 
impasse, isto é, quando o avanço se detinha e passava à condição estática por encontrar força em contrário, também compunha a experiência ibérica, sendo evocada pelo vocábulo. Não será exagero convidar a pensar que enquanto as fronteiras dos Estados-nacionais delimitam, a partir do XIX, o pertencimento a uma comunidade imaginada, os construtos imperiais anteriores compreendiam-nas enquanto pontos de partida para uma constante expansão de seus territórios. $^{15}$

A oposição entre as Coroas no extremo sul da América era atravessada pela presença de diferentes nações indígenas na região, cujas motivações ora coincidiam, ora chocavam-se com as dos europeus. Os espanhóis ostentaram até 1750 uma aliança bem cimentada com os guaranimissioneiro aldeados e catequizados por jesuítas. Mas a decisão de entregar uma porção significativa de suas terras ancestrais aos portugueses, inimigos de longa data, quebrou a aliança e redistribuiu os pontos de equilíbrio na região. Por sua vez, nações de pampeanos - charruas e minuanos - mantinham-se insubordinados a espanhóis e portugueses, embora estabelecessem cooperações com os últimos ou com os guarani-missioneiro. ${ }^{16}$

O cenário foi de permanente disputa, com ambos os impérios procurando estender suas posses às expensas do rival e dos povos indígenas. Os combates foram frequentes, ainda que em diferentes escalas, pois flutuaram de escaramuças entre dezenas de soldados a grandes operações militares com milhares de praças. Neste palco, os regimentos de cavalaria destacaram-se pela mobilidade no relevo com extensas planícies, sendo capazes de deslocamentos rápidos e ataques surpresa. Na segunda metade do XVIII uma grande parte dos enfrentamentos se deu entre pequenas unidades que logo retornavam para pontos seguros. ${ }^{17}$ Os cavalos se tornaram um instrumento de guerra e uma necessidade de primeira ordem, sendo esse um tema que voltará ao nosso foco.

Por mais de uma vez os litigantes ibéricos procuraram soluções diplomáticas aos impasses meridionais. ${ }^{18}$ Em 1750, após negociações cuidadosas, os reis espanhol e lusitano assinaram o

\footnotetext{
15 ANDERSON, Benedict. Nação e consciência nacional. São Paulo: Editora Ática, 1989.

${ }^{16}$ NEUMANN, Eduardo. Fronteira e identidade: confrontos luso-guarani na Banda Oriental, 1680-1757. Revista Complutense de Historia de América, n. 26, 2000. Pp. 73-92.

${ }^{17}$ GIL, Tiago Luís. Coisas do caminho: tropeiros e seus negócios do Viamão à Sorocaba (1780-1810). Tese (Doutorado em História Social), Universidade Federal do Rio de Janeiro, Rio de Janeiro, 2009. GIL, Tiago. Infiéis Transgressores: elites e contrabandistas nas fronteiras do Rio Grande e do Rio Pardo (1760-1810). Rio de Janeiro: Arquivo Nacional, 2007.

18 ALDEN, Dauril. Royal Government in Colonial Brazil. Berkeley e Los Angeles: University of California Press, 1968. ACRUCHE, Hevelly Ferreira. A fronteira e as gentes. Diplomacia, lealdades e soberanias no extremo sul da América Ibérica (1750-1830). Curitiba: Prismas, 2019.
} 
Tratado de Madri, propondo limites bem definidos em áreas de contato na Amazônia e no rio da Prata. O acordo previa o câmbio no controle de certos territórios: a área de sete dos trinta povos missioneiros, por exemplo, deveria ser entregue aos portugueses, sendo seus habitantes comandados a retirarem-se das terras em que habitavam. Face a essa grave ofensa à sua territorialidade ancestral, os guarani-missioneiro deram início a um levante armado contra a execução do tratado, mas sua hostilidade terminou por unir as duas Coroas na repressão. $\mathrm{O}$ desfecho não encerrou as desconfianças existentes entre as comissões demarcatórias e o contrato foi anulado pelo tratado de El Pardo em 1761.

El Pardo ditava o fim do tratado de Madri e o retorno ao indefinido status quo anterior. A retomada da beligerância misturou-se à tensão da Guerra dos Sete Anos (1756-1763) e manifestou-se em um ataque espanhol massivo contra a Colônia do Sacramento (1762) e a vila de Rio Grande (1763). A primeira foi devolvida pelo tratado de Paris, mas a legação espanhola defendeu a tomada de Rio Grande enquanto expulsão de portugueses ilegalmente estabelecidos na região e manteve a vila. Seguiram-se catorze anos de uma guerra não declarada, pois a paz firmada na Europa foi seguida de inúmeras expedições de ambos os lados. Os espanhóis avançaram sobre Rio Pardo sem sucesso em 1762 e 1774, enquanto os portugueses fracassaram na retomada de Rio Grande em 1767. Somente em 1776, e após vitórias estratégicas de menor porte, as forças lusitanas expulsaram seus rivais de Rio Grande graças a uma ação combinada entre as forças de terra e a marinha. O sucesso foi seguido por uma reação fulminante e no ano seguinte os espanhóis caíram novamente sobre a Colônia do Sacramento e também sobre a ilha de Santa Catarina, tomando ambos os locais. Seu avanço só foi freado com a chegada de notícias da Europa: um novo tratado de paz fora firmado e as hostilidades tinham de cessar. ${ }^{19}$ As tratativas se prolongaram até que o Tratado de Santo Ildefonso foi estabelecido em 1777. A Colônia do Sacramento foi finalmente reivindicada em definitivo pela Espanha, que aceitou, por sua vez, trocar uma ilha por outra: Santa Catarina foi devolvida mediante a entrega de Fernando Pó, na costa africana.

A presença portuguesa na região, ao tempo da assinatura e tentativa de demarcação do tratado de Madri, articulava-se a partir de três pontos de referência: Colônia do Sacramento,

\footnotetext{
${ }^{19}$ A narrativa das ações no Rio Grande pode ser acompanhada em GOLIN, Tau. A fronteira (Volume 3): 1763-1778 - História da brava gente e miseráveis tropas de mar e terra que conquistaram o Brasil meridional. Passo Fundo: Méritos, 2015.
} 
Rio Grande e Viamão. Em torno dos mesmos implantaram-se unidades produtivas agropecuárias e rotas comerciais. Esses núcleos populacionais encontravam-se em situações bastante diferentes. A freguesia de Viamão fora formada por famílias ligadas à vila de Laguna e não ostentava contato imediato com os espanhóis, gozando de estabilidade no quesito bélico. A Colônia do Sacramento enfrentava severos obstáculos em articular seu entorno agrário desde 1735-37, quando os espanhóis de Buenos Aires e seus aliados indígenas iniciaram uma política de contenção, para evitar a disseminação lusitana pela Banda Oriental. Apesar da riqueza comercial da praça, a dificuldade em mantê-la orientou a decisão de sua troca pelos territórios missioneiros. A vila do Rio Grande ostentava situação intermediária, estando mais resguardada do que Sacramento por possuir seu próprio forte e devido à combinação entre fortificações avançadas, múltiplas estâncias de gado e alianças com os minuanos. Em relação à freguesia de Viamão, entretanto, encontrava-se bem mais exposta.

Foi neste cenário que o governador e capitão-general do Rio de Janeiro, Gomes Freire de Andrade, atuou para garantir a implantação do tratado de 1750. Uma vez no extremo sul, o Conde de Bobadela determinou a criação de uma nova fortificação, a qual foi iniciada no ponto de encontro entre os rios Pardo e Jacuí, onde uma colina permitia vigiar as planícies que se estendiam a partir das margens opostas. Era o ponto estratégico para estabelecer o forte Jesus Maria José do Rio Pardo (1752), o qual deveria oferecer segurança às famílias açorianas que se destinavam às áreas que seriam incorporadas em virtude do Tratado de Madri, mas que foram barradas pela rebelião guarani. O assentamento em Rio Pardo fez com que a povoação logo se tornasse uma freguesia, sediando também o quartel do Regimento de Dragões. A combinação entre o forte e os rios fez de Rio Pardo um símbolo das disputas na região: oficialmente os portugueses não tinham condições de avançar suas posses, porém, não pretendiam ceder terreno. Rio Pardo e Rio Grande tornaram-se progressivamente os bastiões defensivos lusos na disputada fronteira. O estratagema, entretanto, sofreu um duro revés em 1763, quando os espanhóis conquistaram a vila de Rio Grande. Os aparatos de governo tiveram de se refugiar na freguesia de Viamão, enquanto inúmeras propriedades e pessoas ficaram sob controle de Sua Majestade Católica. Os planos defensivos portugueses foram soprados pelos fortes ventos da belicosidade na região. 
Esse foi o panorama com o qual se deparou o coronel José Marcelino de Figueiredo. A partir de 1763 os portugueses vivenciaram uma nova situação de frontalidade, a qual se materializava especialmente na fortaleza do Rio Pardo e no acampamento de São Caetano, alguns quilômetros ao norte da barra da lagoa e de Rio Grande - agora tomada pelos espanhóis. Os comandantes destes pontos militares foram instruídos pelo governador José Custódio de Sá e Faria em $1764 .^{20}$ Nesse documento, os oficiais encarregados atendiam por comandante do Quartel de Rio Pardo e comandante do acampamento de São Caetano, enquanto seu local de atuação era chamado fronteira. A denominação Comandante de Fronteira surgiu mais tarde, em 1769, já no governo de Marcelino de Figueiredo. Seria mera retórica?

As menções à fronteira do Rio Pardo aumentaram nos anos seguintes. Ela carregava a ideia ambígua de ameaça e oportunidade, exigindo a vigilância aos inimigos e, ao mesmo tempo, abrindo a possibilidade para os roubos de animais e para a continuidade da expansão. Continuar expandindo abriria o acesso a mercês, patentes militares e signos de distinção. Não obstante, como mencionamos acima, a situação era delicada e a Coroa identificara a limitação dos mestres de campo, algo que certamente a fez privilegiar oficiais das tropas pagas para os importantes comandos de Rio Pardo e São Caetano.

O controle espanhol de Rio Grande não apenas subtraíra um território controlado pelos portugueses como colocara os rivais em contato ainda mais imediato do que o previamente existente. Apesar do fracasso em retomar Rio Grande em 1767, as forças lusas ao menos conseguiram fazer os espanhóis recuarem dos terrenos ao norte do canal que liga a lagoa dos Patos ao oceano Atlântico, possibilitando estabelecer uma fortificação, denominada São José do Norte. Por sua vez, em fins de 1773 os espanhóis mobilizaram força considerável em marcha contra Rio Pardo, porém, esta foi desgastada pelos movimentos rápidos da cavalaria lusa, cujos ataques às colunas mais vulneráveis comprometeram a coesão dos atacantes. ${ }^{21}$

$\mathrm{Na}$ busca por respostas mais apropriadas ao desafio de uma fronteira imperial, os governadores da recente capitania do Rio Grande de São Pedro começaram a testar novas formas de organização das tropas, dos territórios e das comunidades. Em 1764 o coronel

\footnotetext{
${ }^{20}$ ARQUIVO HISTÓRICO DO RIO GRANDE DO SUL. Códices de Registro Geral da Real Fazenda do Rio Grande de São Pedro, códice F1242. Registro das Instruções que o Sr. Coronel Governador José Custódio de Sá e Faria deixou ao Tenente-Coronel Francisco Barreto Pereira Pinto, Comandante do quartel do Rio Pardo. Fortaleza de Jesus Maria José do Rio Pardo, 10 de setembro de 1764, fl. 205v-208v. ${ }^{21}$ CHERUBINI, Maria Belén. Una frontera ¿imposible?: los conflictos hispanoportugueses en el sur de América y la expedición a Río Grande de San Pedro (1773). Fronteras De La Historia, 26(2), 2021, p. 238-262. https://doi.org/10.22380/20274688.1409
} 
governador Sá e Faria passou instruções detalhadas ao "comandante do Quartel do Rio Pardo" compostas por vinte itens, os quais buscavam racionalizar os recursos daquele posto defensivo. Instruções de mesmo teor foram enviadas ao comandante do acampamento de São Caetano. As medidas visavam evitar o desgaste dos cavalos, concentrar tropas para que formassem forças eficientes e diminuir o número de passos dos rios. O cuidado em vigiar a posição dos rivais e impedir o acesso de espiões surge nos dois primeiros itens, junto à proibição de roubo de gado em terras espanholas, a fim de não fomentar a retomada das hostilidades.

Em 1769, passado pouco mais de um mês de sua posse no governo, o coronel José Marcelino de Figueiredo emitiu ordens complementares. Estas se valiam de sua experiência anterior à frente do acampamento de São Caetano e traduziam a preocupação em articular os dois pontos de contato com os vizinhos beligerantes. No sétimo dos 33 capítulos que compõem a instrução o governador exigia que a tropa frequentasse a missa aos domingos "em forma como também eu praticava no Acampamento de São Caetano”. Menções similares aparecem nos capítulos 24 e 27. Figueiredo buscava aprimorar a mobilização militar e a administração daquelas fronteiras portuguesas, alterando a denominação dos comandantes de quartéis para Comandantes de Fronteira. A mudança sugere que deveriam se responsabilizar não somente pelo quartel imediato de sua tropa ou pela localidade na qual tinham suas bases, mas por uma região mais extensa, onde a beligerância frente aos espanhóis seria a tônica. É oportuno salientar que José Marcelino comandara o acampamento de São Caetano, tendo acessado as ordens emitidas por Sá e Faria alguns anos antes.

Em suas instruções, Figueiredo menciona "duas Fronteiras desta Província", diferenciando um território mais amplo - a capitania do Rio Grande, por ele referida como "província" - dentro do qual se encontravam áreas específicas: as fronteiras de Rio Pardo e do Norte $^{22}$. Com a reconquista da vila de Rio Grande em 1776, a denominação "Fronteira do Norte" viria a caducar, sendo substituída por "Fronteira do Rio Grande". Afinal, ao retornar para o domínio luso, essa vila voltou a ser o principal ponto no extremo sul da capitania, servindo a partir de então de base para a Fronteira de mesmo nome, a qual também incorporou o território da antiga Fronteira do Norte. O sistema de designar comandantes para essas duas

\footnotetext{
${ }^{22}$ A Fronteira do Norte refere-se ao norte do canal da lagoa e da vila de Rio Grande, localizando-se, entretanto, mais ao sul do que a freguesia de Viamão e da maior parte dos povoados. Nesse sentido, a Fronteira do Norte não fazia menção ao norte da capitania.
} 
áreas com "mais ou menos imediação com os Castelhanos" visava diminuir o tempo de resposta nesses pontos nevrálgicos da concorrência ibérica. Cada comandante consistia de "um oficial a quem se encarrega o grande emprego do Comando de uma Fronteira pois tem jurisdição na Tropa, nos Auxiliares e Ordenanças de toda ela", estando a frente de todas as tropas necessárias em caso de ofensiva espanhola, ao mesmo tempo em que devia disciplinar e organizar a população lusitana. ${ }^{23}$

O aprimoramento apresentado pela instrução de 1769, entretanto, não efetuou uma ruptura brusca com a organização militar vigente na capitania. A concepção dos Comandantes de Fronteira resultou da continuidade na guerra contra espanhóis (e indígenas, em menor escala), mas também da limitação do governador em estar presente nos diferentes palcos de guerra. Simultaneamente, os portugueses preocupavam-se em regular a circulação de pessoas, bens e informações, algo que se materializava, por exemplo, nas atividades de contrabando, nas fugas de escravos e nas deserções. Nesse sentido, a delegação de tarefas do governador a oficiais da primeira linha, em locais distantes da sede do governo, visava também aumentar a eficácia do controle da Coroa sobre seus súditos. Paradoxalmente, muitos dos agentes militares encarregados deste controle eram praticantes de contrabando. ${ }^{24}$

Ainda assim, a Coroa lusa, através do governador da capitania, reconhecia e reforçava a figura dos comandantes militares, considerando-os indicados a exercer essas funções em cada uma das áreas limítrofes da capitania e designando para cada uma delas um Comandante de Fronteira. Em alguma medida, tratava-se de adaptar a experiência dos mestres de campo em organizar as comunidades, mas desta vez, ao privilegiar oficiais das tropas pagas, esperava-se contornar o fortalecimento de lideranças locais, pois a urgência de uma fronteira imperial impunha necessidades específicas e imperativas.

Os Comandantes de Fronteira surgiram também da necessidade de dividir a organização militar e de defesa da capitania, centralizando o comando geral das forças em cada uma das fronteiras do território sob jurisdição do governador. Seu surgimento pode ser igualmente compreendido dentro do processo de "militarização do território". Tal processo

\footnotetext{
${ }^{23}$ Arquivo Histórico do Rio Grande do Sul. Códices de Registro Geral da Real Fazenda do Rio Grande de São Pedro, códice F1243.Registro de uma instrução e ordens para os Comandantes das Fronteiras que devem observar, passada pelo Sr. Coronel Governador José Marcelino de Figueiredo. Fortes de São José do Norte, 15 de junho de 1769, fl. 197-201v.

${ }^{24}$ GIL, 2007
} 
[...] remete, sobretudo para as inevitáveis tentativas de subordinação das populações, quer a modalidades de recrutamento mais eficientes, quer a um quadro militar mais disciplinador, sempre de forma a enfrentar conjunturas marcadas pela guerra. Nesse sentido, o processo de enquadramento militar de populações constituiu uma outra forma de abordar o território, a que estiveram naturalmente associadas dinâmicas de conflito. ${ }^{25}$

Ao mesmo tempo, compreendemos que a modificação efetuada pelo governador Figueiredo consistiu na racionalização da administração cotidiana dos territórios e das populações, considerando o papel que os Comandantes de Fronteira rapidamente passaram a ter no governo da capitania. Tais comandantes não constituíram um poder concorrente, pois estavam diretamente subordinados ao governador, e converteram-se também em agentes vinculados ao governo da capitania em cada uma das fronteiras, sendo oficiais bem considerados por seus subordinados e superiores, além de capazes de impor a autoridade em nome do rei. Conforme o governador manifestou ao vice-rei na década de 1770 , os oficiais graduados que fossem encarregados no Comando das Fronteiras necessitavam ter "capacidade para poderem responder aos Espanhóis ali confinantes e descansarem-me entre tanto trabalho que tenho com tanto gosto em executar as ordens de V. Ex. ${ }^{\text {a }}$ relativas ao aumento, e estabelecimento desta Capitania"26.

O descanso ao qual referia-se o governador também dizia respeito ao trânsito entre as fronteiras da capitania. A iminência da guerra em duas frentes distintas, associada à distância em que essas duas áreas se encontravam da sede do governo e, principalmente, uma da outra, foram elementos que pesaram no surgimento dos Comandantes de Fronteira, uma vez que dificultavam que o governador pudesse responder de maneira efetiva e presencial às demandas de cada uma. É o que se pode depreender da correspondência do governador com o vice-rei, quando aquele solicitava reiteradamente o envio de oficiais suficientes para comandar as

${ }^{25}$ CRUZ, Miguel Dantas da. A militarização do território no Brasil Meridional (c.1766-1800). In: MOTA, Márcia; SERRÃO, José Vicente; MACHADO, Marina (Org.) Em terras lusas: conflitos e fronteiras no Império Português. Vinhedo: Editora Horizonte, 2013, p. 105.

${ }^{26}$ CARTAS do Governador José Marcelino de Figueiredo para o Vice-rei, Marquês do Lavradio (1773). Revista do Instituto Histórico e Geográfico do RGS, ano 90, n. 144, 2010, p. 186. 
fronteiras. Tendo informações de que tropas espanholas se dirigiam à capitania, Figueiredo escreveu da Fronteira do Norte ao vice-rei em novembro de 1773, noticiando o seguinte:

\begin{abstract}
Depois de ter dado conta a V. Ex. a dos movimentos e procedimentos do Espanhóis nesta Fronteira, me chega parada do Rio Pardo com as notícias que V. Ex. ${ }^{a}$ verá das cópias inclusas, e como nem nesta, nem naquela há comandante suficiente, pela moléstia de um, e falta de graduação de outro, não sei a qual deva acudir, e fico na consternação que V. Ex. ${ }^{a}$ deve supor, sem poder acudir as duas fronteiras, em distância uma da outra de cento e tantas léguas. ${ }^{27}$
\end{abstract}

Menos de um mês depois, já na capital Porto Alegre, o governador informava ao vice-rei que adiantara o plano de defesa para a Fronteira do Rio Pardo por "não poder estar em todas as partes ao mesmo tempo", chegando a afirmar sobre a falta de oficiais nas Fronteiras: "V. Ex." sabe que eu estou só, e sou obrigado a andar de Fronteira em Fronteira, com viagens de centos de léguas, e se romper a guerra em todas, eu só posso estar em uma" ${ }^{28}$. As distâncias eram um obstáculo relevante e a impossibilidade de estar pessoalmente à frente das ações em cada fronteira prenunciava prejuízos de primeira ordem. Tanto o é que tais circunstâncias levaram o governador a concluir posteriormente que "o serviço das Conquistas se faz insuportável pelas distâncias" 29 . Nesse sentido, é muito provável que a necessidade de suprir essa demanda foi um dos fatores que levaram o governador a instituir os Comandantes de Fronteira, delegando poderes que os permitissem estar à frente das ações em cada uma das fronteiras, mas sob ordens diretas do próprio governador.

Ao atualizar os comandantes de quartéis com a denominação de Comandante de Fronteira, Figueiredo mantinha a organização militar da capitania e suas atribuições, adaptando algumas práticas, como o atestam alguns elementos presentes nas Instruções de 1769. A $29^{a}$ ordem trata de elucidar como o Comandante de Fronteira deveria ser saudado pelas guardas, sendo descritas as variações nessa saudação para as patentes de capitão, sargento-mor, tenente-

\footnotetext{
${ }^{27}$ CARTAS do Governador José Marcelino de Figueiredo para o Vice-rei, Marquês do Lavradio (1773). Revista do Instituto Histórico e Geográfico do RGS, ano 90, n. 144, 2010, p. 194.

28 CARTAS do Governador José Marcelino de Figueiredo para o Vice-rei, Marquês do Lavradio (1773). Revista do Instituto Histórico e Geográfico do RGS, ano 90, n. 144, 2010, p. 194.

${ }^{29}$ BIBLIOTECA NACIONAL. Coleção Martins, 13, 06, 06. Correspondência de José Marcelino de Figueiredo com o General João Henriques Bohm. 1774-1776, fl. 444-445.
} 
coronel e coronel - o que também indica que o posto poderia ou deveria ser ocupado por oficiais com essas graduações. Já a $30^{\mathrm{a}}$ descreve como seria o cerimonial de recepção desses comandantes pelas tropas. A necessidade de explicitar como os Comandantes de Fronteira deveriam ser saudados pelos seus subordinados indica que essa era uma modificação no modo como a tropa deveria se portar perante aquele que ocupasse tal cargo a partir de então. Nesse sentido, há que se considerar que tal explicação não seria necessária caso o cargo já existisse anteriormente, o que reforça o argumento de que os Comandantes de Fronteira foram instituídos pelo governador Figueiredo através da instrução de 1769. Na medida em que os itens dessa instrução definiram atribuições do cargo, eles também sugerem do que se tratava o posto, motivo pelo qual passaremos a discorrer sobre tais atribuições a partir dos itens presentes nesse documento.

\section{"A QUEM SE ENCARREGA O GRANDE EMPREGO DE COMANDANTE DE UMA FRONTEIRA": OS COMANDANTES DE FRONTEIRA E SUAS ATRIBUICÕES}

Identificamos que os Comandantes de Fronteiras foram assim nomeados nas Instruções de 1769. Ao prever atribuições e funções a oficiais específicos das tropas regulares, terminouse por criar um cargo, que se manteve existente nas décadas seguintes, adentrando o período do Brasil independente. A abertura do documento menciona ser uma "instrução de ordens que deixo para se regular o serviço das tropas das Fronteiras desta Província”, a qual se compunha de 33 capítulos bastante diversos. Ao pensarmos a direção geral dessas orientações, podemos afirmar que procuravam organizar e disciplinar as tropas em sua atividade cotidiana.

Ao invertemos a sequência dos capítulos, averiguamos que o $33^{\circ}$ afiança que o Comandante de Fronteira consistia em "um oficial a quem se encarrega o grande emprego do Comando de uma Fronteira pois tem jurisdição na Tropa, nos Auxiliares e Ordenanças de toda ela", isto é, as forças que atuavam num dos territórios da capitania estavam submetidas a este encarregado, o qual se subordinava apenas ao governador. Significa que longe da capital estabelecida em Viamão em 1763 e transferida para Porto Alegre em 1773 - as diferentes linhas de defesa seriam organizadas por um único responsável, evitando, desse modo, conflitos sobre precedência, em favor de uma resposta unificada frente ao inimigo. Tal cenário impunha aos 
comandantes tarefas relativas à defesa tanto quanto à expansão das posses lusitanas. Os Comandantes de Fronteira eram encarregados de múltiplas tarefas, devendo atuar propriamente na ação bélica e atender à organização e abastecimento das tropas pagas.

Uma grande parte das instruções, e em particular as inseridas no início do documento, incidem sobre a necessidade de estabelecer a disciplina dentro das tropas pagas, relacionando esta exigência ao bom preparo e desempenho dos soldados. Sobre este tema identificamos 11 capítulos, sendo o mais recorrente. A exigência sobre realizar exercícios e manter a prontidão aparece próxima à manutenção da disciplina e é abordada em 4 capítulos, sendo que o $11^{\circ}$ menciona ambos os temas.

Complementarmente, a manutenção de ações de vigilância, as quais envolviam patrulhas e a observação dos movimentos dos espanhóis, mostra-se próxima dos temas da disciplina e da prontidão, sobrepondo-se aos mesmos nos artigos $9^{\circ}$ e $11^{\circ}$. De fato, no primeiro deles há menção explícita sobre "avisar-me de todos os movimentos que souber fazem os espanhóis da banda do Sul desta Barra". ${ }^{30}$ Esta preocupação já surgira nas instruções de 1764 ao comandante do Quartel de Rio Pardo, nas quais se orientava a "examinar os movimentos dos nossos vizinhos por esta parte". ${ }^{31}$ Décadas mais tarde a busca por informação, a fim de acompanhar e, se possível, antecipar as iniciativas espanholas estava na ordem do dia dos Comandantes de Fronteira, os quais mobilizavam informantes e pagamentos para abastecer seus superiores de notícias. ${ }^{32} \mathrm{O}$ próprio vice-rei Marquês do Lavradio havia expedido instruções para o uso e pagamento das "espias necessárias". 33

A preocupação da disciplina coaduna-se com as instruções que orientavam aos castigos por desobediência, contemplados não apenas os soldados e oficiais inferiores, mas mesmo os superiores. Três artigos dedicam-se à temática. As punições a crimes, contudo, tem um único artigo, o qual ordenava coibir os roubos de gado e o contrabando, além de restituir os bens

\footnotetext{
${ }^{30}$ ARQUIVO HISTÓRICO DO RIO GRANDE DO SUL. Códices de Registro Geral da Real Fazenda do Rio Grande de São Pedro, códice F1243. Registro de uma instrução e ordens para os Comandantes das Fronteiras que devem observar, passada pelo Sr. Coronel Governador José Marcelino de Figueiredo. Fortes de São José do Norte, 15 de junho de 1769, fl. 197-201v.

31 ARQUIVO HISTÓRICO DO RIO GRANDE DO SUL. Códices de Registro Geral da Real Fazenda do Rio Grande de São Pedro, códice F1242. Registro das Instruções que o Sr. Coronel Governador José Custódio de Sá e Faria deixou ao Tenente-Coronel Francisco Barreto Pereira Pinto, Comandante do quartel do Rio Pardo. Fortaleza de Jesus Maria José do Rio Pardo, 10 de setembro de 1764, fl. 205v-208v.

${ }^{32}$ COMISSOLI, Adriano. Bombeiros, espias e vaqueanos: agentes da comunicação política no sul da América portuguesa (Rio Grande de São Pedro, séc. XVIII-XIX). Revista de Índias. Volume LXXVIII, Número 272, 2018, p. 113-146.

${ }^{3}$ ARQUIVO HISTÓRICO DO RIO GRANDE DO SUL (AHRS), Fundo Fazenda, códice F1244, fls. 27v. e 28, Registro de uma portaria que o Tenente-coronel Governador para se registrar o capítulo de uma carta do Ilmo. E Exmo. Sr. Marquês Vice-rei do Estado sobre as espias que são necessárias, 19/05/1772.
} 
roubados "na forma do costume nesta Província". ${ }^{34}$ A falta de detalhes se explica parcialmente por serem os crimes já contemplados em legislação régia, mas também por que instruções como as emitidas em 1764 abordavam o problema de forma mais explícita. É interessante notar que a versão de 1769 justifica a repressão aos crimes pela necessidade de "que não haja menor motivo de queixa para os Espanhóis", dando a entender que o problema residia mais na repercussão diplomática do que na inobservância da lei. ${ }^{35}$

Um tema bastante abordado nas instruções aos comandantes diz respeito à administração dos meios materiais para a defesa do território. São 16 os artigos que tratam dos diferentes recursos mobilizados: humanos, animais e materiais. Para além de todos os artigos mencionando a imprescindibilidade da disciplina, outros 4 abordam a necessidade de manter abastecido o hospital e orientam a expedição de licenças, bem como seu protocolo. Nota-se a preocupação em premiar ou compensar as forças militares, compreendendo o quão comuns eram os pedidos de licenças, uma visão pragmática do gerenciamento das tropas, que procurava se antecipar às tradições de resistência ao serviço militar.

Recursos materiais inanimados como o abastecimento das tropas e o racionamento da pólvora aparecem em 7 capítulos, implicando que uma parte significativa dos esforços de comando dirigia-se ao aprovisionamento. Já os cuidados a praticar com animais, especificamente os cavalos, somam 6 capítulos. Sobre a força equina havia a preocupação com o desgaste, com ordens expressas de reservar os animais ao serviço régio. Os cavalos ocupavam um lugar especial nas operações militares meridionais, equipando patrulhas e rotas de mensageiros, além de serem usados por peões nas atividades pecuárias - igualmente necessárias para as atividades militares, não só para o cuidado do gado destinado à alimentação das tropas, como também para o cuidado dos cavalos destinados ao serviço. A ênfase neste recurso não era exagerada, dado que em inúmeros ofícios entre 1750 e 1812 as menções ao mau estado dos animais ou ao seu número reduzido são comuns. Para uma região que contava milhares de cavalos e éguas, parecia nunca haver o suficiente para o serviço régio.

\footnotetext{
${ }^{34}$ ARQUIVO HISTÓRICO DO RIO GRANDE DO SUL. Códices de Registro Geral da Real Fazenda do Rio Grande de São Pedro, códice F1243. Registro de uma instrução e ordens para os Comandantes das Fronteiras que devem observar, passada pelo Sr. Coronel Governador José Marcelino de Figueiredo. Fortes de São José do Norte, 15 de junho de 1769, fl. 197-201v.

${ }^{35}$ ARQUIVO HISTÓRICO DO RIO GRANDE DO SUL. Códices de Registro Geral da Real Fazenda do Rio Grande de São Pedro, códice F1243. Registro de uma instrução e ordens para os Comandantes das Fronteiras que devem observar, passada pelo Sr. Coronel Governador José Marcelino de Figueiredo. Fortes de São José do Norte, 15 de junho de 1769, fl. 197-201v.
} 
Embora relevante, a preocupação com os cavalos compunha apenas uma das diversas atribuições que os Comandantes de Fronteira passaram a ter a partir do surgimento desse cargo em 1769, como se pode perceber pelos itens da instrução emitida nesse ano. Ao longo das décadas seguintes, essas atribuições se complexificaram, à medida em que tais comandantes adquiriram centralidade no governo das gentes e dos territórios da capitania. Atuando em jurisdições menores do que a totalidade da capitania, os Comandantes de Fronteira terminaram por intervir diretamente na organização e funcionamento cotidiano da sociedade, trabalhando também como administradores.

Helen Osório destacou a preocupação das autoridades com o regulamento das criações equinas no Rio Grande, com vistas ao crescimento econômico e às necessidades das guerras. ${ }^{36}$ A preocupação com os cavalos - seja para seu uso nas atividades econômicas ou no serviço militar e na guerra - era tanta que motivou a elaboração e o envio de algumas propostas ao Conselho Ultramarino, com vistas ao disciplinamento das criações na capitania, para além das medidas constantes levadas à cabo nesse mesmo sentido. ${ }^{37} \mathrm{Em}$ uma dessas propostas, datada de 1784, há um apartado que discorre especificamente sobre as cavalhadas dos particulares e sua regulamentação. ${ }^{38}$ Conforme um dos artigos desse apartado, o governador deveria determinar "aos Comandantes de Fronteira que nos distritos que pertenciam a cada uma delas" fizessem valer o conteúdo da proposta, fiscalizando sua execução e também elaborando relações anuais dos cavalos mansos existentes nas estâncias dos particulares, as quais seriam enviadas ao governador, que por sua vez as encaminharia ao vice-rei. ${ }^{39}$ Por mais que não tenha sido implementada ${ }^{40}$, tal proposta evidencia não apenas a importância dos cavalos para a defesa e o governo da capitania, como também o papel que os Comandantes de Fronteira exerciam nesses âmbitos, tendo em vista a responsabilidade que recairia nos ocupantes desses cargos.

\footnotetext{
${ }^{36}$ OSÓRIO, Helen. O império português no sul da América: estancieiros, lavradores e comerciantes. Porto Alegre: Editora da UFRGS, 2007. ${ }^{37}$ OSÓRIO, 2007

38 REGULAMENTO para a conservação dos animais das fazendas e estâncias dos particulares. Transcrito em SANTOS, Corcino Medeiros dos. Economia e sociedade do Rio Grande do Sul: século XVIII. São Paulo: Ed. Nacional; Brasília: INL, Fundação Nacional Pró-Memória, 1984, p. 193-202.

${ }^{39}$ Em nota de rodapé, Helen Osório chama a atenção para essa atribuição que seria incumbida aos Comandantes de Fronteira. OSÓRIO, 2007, p. 133 , nota 97.

40 OSÓRIO, 2007
} 
Não por acaso, a seguinte reclamação foi encaminhada pelo alferes Francisco Barreto Pereira Pinto a Patrício José Corrêa da Câmara, Comandante da Fronteira do Rio Pardo, em 1801:

\begin{abstract}
As duas companhias de auxiliares que V.M. promete incorporarem-se, não só não tem chegado, como são as daquele regimento as menos aptas para fazer serviço nesta campanha, já por serem gente mais pobre, e por isso com menos e mais maus cavalos, como serem (por maior parte) Lavradores, e não Estancieiros, que são os mais hábeis para o serviço de cavalo $\left[\ldots . .{ }^{41}\right.$
\end{abstract}

Como se pode perceber, a preocupação com os cavalos pertencentes aos particulares era do interesse das autoridades porque estava baseada nas necessidades concretas vivenciadas em virtude das situações de guerra e da defesa dos territórios. Fazia sentido, portanto, que os Comandantes de Fronteira fossem também responsáveis pela regulação da criação de cavalos nos territórios sob seu governo, como pretendia a proposta, uma vez que os ocupantes de tais postos centralizavam as responsabilidades sobre a defesa e a guerra nas fronteiras que comandavam. Porém, preparar-se para a guerra demandava inúmeros recursos, motivo pelo qual os Comandantes de Fronteira eram instruídos a dedicar bastante tempo a fiscalizar as atividades produtivas.

Um dos artigos da proposta enviada ao Conselho Ultramarino chegou a mencionar a possibilidade de quintar - cobrar o imposto de $20 \%$ - aqueles produtores que não cumprissem as disposições previstas, estimulando sua prática pela ameaça de punição. Os Comandantes de Fronteira, ao fim e ao cabo, estavam responsáveis pelo equilíbrio entre a ameaça de executar cobranças de impostos e as orientações a solicitar cavalos dos proprietários - fossem grandes ou pequenos - sul-rio-grandenses, operando como agentes de implantação das diretrizes régias. Conforme já afirmamos, entretanto, tais propostas nunca chegaram a ser implementadas, o que nos aponta para o fato de que também a Coroa lusa conhecia seus limites nos governos de possessões tão diversas quanto distantes de Lisboa. À parte isso, conhecer o número exato de cavalos disponíveis, bem como seus diferentes níveis de adestramento, se xucros ou

\footnotetext{
${ }^{41}$ ARQUIVO NACIONAL. Códice 104. Volume 13. Francisco Barreto Pereira Pinto ao Ten. Cel. Patrício José Correa da Câmara. Guarda de São Pedro, 22 de julho de 1801. fl. 180 apud OSÓRIO, 2007, p. 169.
} 
domados, se marcados e a quem pertenciam, era uma necessidade que se colocava àqueles que atuavam no governo da capitania. Ela implica um nível bastante detalhado de controle sobre um recurso considerado fundamental no ambiente belicista do extremo sul. É importante destacar, entrementes, que a proposta de realizar o trabalho de modo minucioso só foi produzida após os anos de guerra viva, durante o governo de Sebastião Xavier da Veiga Cabral da Câmara (1780-1801). A preocupação, como vimos, já deitava raízes de 15 anos e é oportuno argumentar que durante um período de maior tranquilidade os agentes da Coroa avançaram no controle sobre as comunidades e suas produções, criando planos de contingência para possíveis novos embates.

Na comunicação do alferes Francisco Barreto Pereira Pinto ao comandante Patrício José Corrêa da Câmara em 1801 é possível identificar os cuidados para com os animais e igualmente a mobilização das forças de milícias (como as tropas auxiliares passam a ser designadas em 1796). Para a Coroa, o recurso a estas forças significava multiplicar o número de homens defendendo a capitania, sem, contudo, aumentar as despesas para a Fazenda Real. Bons soldados, entretanto, necessitavam de bons cavalos, do contrário seu uso se limitava radicalmente.

A situação de guerra no extremo sul mobilizava primeiramente as tropas pagas, as quais desde a Guerra de Restauração se procurava ter por princípio da defesa. ${ }^{42}$ Em segundo nível eram utilizados os auxiliares, requisitados com grande frequência, tanto por seu número quanto por seu conhecimento do terreno, o qual originava-se do trabalho nas mais diversas atividades agropastoris. As ordenanças, por fim, eram pouco ou nada mobilizadas, realizando exercícios nas freguesias ou vigiando-as na ausência das duas primeiras forças. As tropas de ordenanças foram enaltecidas pelo vice-rei Marquês do Lavradio em seu famoso relatório de final de governo, quando foram apontadas enquanto esteio para a defesa da cidade do Rio de Janeiro um intenso porto marítimo. Em outra parcela das possessões ultramarinas de Sua Majestade Fidelíssima, entretanto, os deslocamentos frequentes da cavalaria exigiam outro perfil das tropas, mais adequado às planícies meridionais. É bastante possível que por tal motivo as forças de primeira linha e auxiliares atraíssem as famílias dos súditos partícipes dos primeiros

\footnotetext{
${ }^{42}$ COSTA, 2010, p. 159
} 
momentos de formação da capitania - com destaque ao regimento de Dragões - enquanto as ordenanças concentrassem oficiais dentre o grupo mercantil, fortemente atrelado à Câmara. ${ }^{43}$

A pretensão de José Marcelino de Figueiredo de governar a partir da freguesia de Porto Alegre, tornada capital em 1773, colocou os Comandantes de Fronteira enquanto correias de transmissão de suas ordens, responsáveis tanto pelas forças de $1^{\mathrm{a}}$ quanto de $2^{\mathrm{a}}$ linha. Contudo, havia oficiais difíceis de controlar, como Rafael Pinto Bandeira e seus irmãos, bastante atuantes no roubo de gado aos espanhóis e na entrada ilícita dos animais em território português. Rafael deixara o prestigiado regimento de Dragões em favor das tropas auxiliares, notadamente a recém-criada cavalaria ligeira, a qual lhe oferecia formas de cooptar aliados dentre os grupos subalternos da capitania, incluindo peões de estância livres ou escravizados, indígenas de diferentes etnias e soldados que haviam desertado das tropas regulares. Sendo capaz de ampliar os efetivos militares e obtendo vitórias importantes contra os rivais hispânicos, Rafael terminava por figurar na correspondência entre as autoridades em alternância entre a represália e a parabenização, sendo-lhe tolerados os crimes praticados. ${ }^{44}$

Outro fator importante dizia respeito ao envolvimento dos Comandantes de Fronteira na concessão de terras aos súditos de Portugal. Pelo edital de concessão de terras, de 1780, os requerimentos deveriam ser informados "pelos Comandantes das Fronteiras, ou dos lugares", uma definição que colocava os oficiais na condição de confirmar ou desaprovar as informações a serem repassadas ao governador, influenciando fortemente a repartição de terras nas áreas sob seu comando. Segundo Helen Osório, nem a Câmara nem o Provedor da Fazenda foram ouvidos nas circunstâncias do Edital, o que reforça o papel dos Comandantes de Fronteira. ${ }^{45}$ De fato, Adriano Comissoli aponta que a Câmara em Porto Alegre não regrava sequer a concessão de chãos no centro populacional da vila, não sendo consultada para autorizações referentes à área propriamente rural. ${ }^{46}$

\footnotetext{
${ }^{43}$ COMISSOLI, Adriano \& GIL, Tiago Luís. Camaristas e potentados no extremo da Conquista, Rio Grande de São Pedro, 1779-1810. In. FRAGOSO, João; SAMPAIO, Antônio Carlos Jucá de. Monarquia pluricontinental e a governança da terra no ultramar atlântico luso: séculos XVI-XVIII. Rio de Janeiro: Mauad X, 2012.

${ }^{44}$ OSÓRIO, Helen. Apropriação da terra no Rio Grande de São Pedro e a formação do espaço platino. Dissertação (Mestrado em História), Universidade Federal do Rio Grande do Sul, Porto Alegre, 1990, p. 171-172.

45 OSÓRIO, 1990. OSÓRIO, 2007.

${ }^{46}$ COMISSOLI, Adriano. Os “homens bons" e a Câmara municipal de Porto Alegre (1767-1808). Porto Alegre: Gráfica da UFRGS, 2008. p. 125 .
} 
José Marcelino de Figueiredo, idealizador da designação dos oficiais responsáveis pelos pontos de fronteira, mostrou preocupação com as concessões de terras que vinham sendo realizadas por João Henrique de Böhn a partir da retomada de Rio Grande. Em 1776 escrevia ao vice-rei Marquês do Lavradio:

Consta-me que já no Rio Grande se tem dado algumas posses de terras (o que nesta fronteira [de Rio Pardo] ainda não permiti, suposto há bastantes) e não sei se isto pertence ao Comando de tropas ou ao Econômico e Civil do Continente, ouvindo eu o Provedor e a Câmara [...]. ${ }^{47}$

A redação desta observação, contudo, pode ser colocada dentro da disputa que Marcelino de Figueiredo travava com João Henrique de Böhn. O governador ansiava por determinar quais suas atribuições e quando deveria ceder ao tenente-general. Da mesma forma, havia a indefinição sobre o território administrado por cada um. A recém-reconquistada vila do Rio Grande voltaria a compor a capitania ou passaria a compor um novo recorte, uma nova jurisdição de algum tipo? O resultado incidiu sobre a primeira alternativa, com a nomeação de novo Comandante de Fronteira do Rio Grande. E tal qual seu congênere de Rio Pardo, esse comandante também assinou inúmeros pedidos de informação sobre ocupação de terras, a fim de confirmar ou negar as solicitações de vassalos. Da mesma forma, avaliavam queixas de invasão em terras ocupadas e forneciam dados para as decisões do governador.

Uma função importante desempenhada pelos Comandantes de Fronteira esteve associada ao ramo da Justiça. A territorialização da justiça no império português incidiu no protagonismo de ouvidores, governadores e Câmaras, considerada a diversidade de situações contidas no grande construto pluricontinental. ${ }^{48}$ O Rio Grande de São Pedro se enquadra nesse painel, dado que a capitania foi atendida entre 1749 e 1812 pela comarca da ilha de Santa Catarina e por uma única Câmara, entre 1747 e 1810, mas a Justiça ligou-se, em grande medida, às ações dirigidas pelo governador, que delegava aos Comandantes de Fronteira e demais

\footnotetext{
47 CARTAS do Governador José Marcelino de Figueiredo para o Vice-rei, Marquês do Lavradio (1776). Revista do Instituto Histórico e Geográfico do RGS, ano 93, n. 147, 2013, p. 183.

${ }^{48}$ CUNHA, Mafalda Soares da; NUNES, António Castro. Territorialização e poder na América portuguesa. A criação de comarcas, séculos XV-XVIII. Tempo, v. 22, n. 39, pp. 01-30, jan-abr. 2016.
} 
oficiais das tropas pagas a prisão de criminosos, a apuração de crimes, a administração do calabouço, o deslocamento de presos e a remessa de grilhões e correntes. ${ }^{49} \mathrm{Na}$ ausência de uma Justiça profissional na capitania - dado que o ouvidor habitava na ilha de Santa Catarina - os Comandantes de Fronteira desempenharam parte significativa das tarefas regularmente atribuídas a juízes de fora e ouvidores. É factível que a Coroa portuguesa tenha resistido a designar ministros territoriais para o Rio Grande por apoiar-se nos militares, o que reforçava a figura do governador. Nesse caso estamos tratando menos de uma territorialização da justiça do que de uma militarização do território.

Essa manifestação não se apresentava de modo totalmente coerente, já que o próprio Marcelino de Figueiredo solicitou em 1779 que fossem criados juízes ordinários nos povoados de Rio Grande e de Rio Pardo, mas sem que estes fossem elevados a vilas. ${ }^{50}$ Em 1791, o brigadeiro Rafael Pinto Bandeira advogou o estabelecimento de três vilas, nos mesmos povoados que sediavam os quartéis militares: "Porto Alegre, parece ser, o verdadeiro Lugar, para Capital deste Continente, donde se deverá conservar tudo que sobra em as Fronteiras, e especialmente nesta a risca de cima do Rio Grande. Era bom Exmo. Sr. Porto Alegre ser uma vila, e Rio Pardo outra". ${ }^{51}$ Contudo, os vice-reis ignoraram essas sugestões, o que sugere que o sistema de Comandantes de Fronteira encontrava aceitação nos círculos decisórios do império. Se as recomendações de Marcelino de Figueiredo influenciaram a criação dos Comandantes de Fronteira - os quais aparentemente não foram reproduzidos em outras capitanias - o bom funcionamento dessa organização fez com que sistemas mais tradicionais não tenham sido implantados.

Muitas atividades exercidas pelos Comandantes de Fronteira se aproximavam dos ramos "administrativos" ou de "polícia". 52 A permanência desses comandantes os fez atuar frequentemente na repressão aos crimes, ao perseguir assassinos e contrabandistas, procurar por escravos fugidos ou negociar a devolução dos mesmos junto aos oficiais espanhóis, transportar

\footnotetext{
${ }^{49}$ PICCOLI, Andréia Aparecida. Julgar a cada um o que é seu: justiça e criminosos nos domínios portugueses da Fronteira Platina (1777ca. 1810ca.). Universidade de Passo Fundo, Passo Fundo, 2019, p. 14-15

${ }^{50}$ CARTA do Governador José Marcelino de Figueiredo para o Vice-rei, Marquês do Lavradio (24 de março de 1779). Revista do Museu e Archivo Público do Rio Grande do Sul, n. 23, jun/1930, p. 405.

${ }^{51}$ ARQUIVO HISTÓRICO ULTRAMARINO, cx. 3, doc. 252. Ofício do Brigadeiro Rafael Pinto Bandeira a Martinho de Melo e Castro, 29 de fevereiro de 1791.

${ }^{52}$ COMISSOLI, Adriano; VIANNA, Clarissa Prestes Medeiros. Governadores e generais: comunicação, inteligência e defesa no Rio Grande de São Pedro português. Revista Navigator, v. 13, p. 11-24, 2017.
} 
presos ou vigiar as prisões junto aos quartéis. ${ }^{53}$ Dentre outras iniciativas, as autoridades preocuparam-se com os grupos considerados indesejados, qualificados enquanto "hombres sueltos", "vagamundos", "vadios" ou "contrabandistas" 54 . O controle que se tentava exercer sobre o trânsito de pessoas, bens e informações, incidia incisivamente sobre esses grupos, considerados "criminosos" e "sem domicílio certo", ainda que muitos ostentassem vínculos regulares com os proprietários de terras ${ }^{55}$ e provavelmente tivessem migrado para a região atraídos por oportunidades econômicas. Bandos emitidos por três governadores diferentes permitem evidenciar as tentativas das autoridades portuguesas em impor a emissão e fiscalização de licenças escritas, algo que também foi pretendido nos territórios espanhóis. ${ }^{56}$

Os governadores reiteradamente ordenaram aos oficiais militares que emitissem e fiscalizassem as licenças de trânsito. José Custódio de Sá e Faria, em 1765, José Marcelino de Figueiredo, em 1769 e 1773, e o governador interino Antônio da Veiga Andrade, também em 1773, emitiram bandos, anunciados à toda a população da capitania. No mais antigo deles inseria-se um "edital" “insultos, roubos, e mortes" ocasionados "pelos escravos dos Senhores de Engenho, e pessoas agregadas aos mesmos, que fiadas nos respeitos destes, se atrevem a cometer semelhantes delitos". Nesta primeira manifestação a vigilância estava confiada ao ajudante de ordens do governador, ou aos capitães das ordenanças, ou aos "Comandantes dos Quartéis deste Governo", todos os quais deveriam remeter os presos ao governador. É importante notar que a nomenclatura Comandante de Fronteira não havia sido adotada, ainda que se buscasse delimitar as incumbências militares.

Este primeiro bando seria mencionado no de 1769, que por sua vez avaliava que o território estava “infestado de ladrões facinorosos, matadores, desertores, e Índios dispersos por todas as partes desta Província", e que era necessário para "a extinção de semelhantes gentes" que concorressem "todos os Vassalos de El Rey Nosso Senhor, como devem e são obrigados cada um na parte que lhe toca". A solução passava por mobilizar os oficiais de milícias, de

\footnotetext{
${ }^{53}$ PICCOLI, 2019.

${ }^{54}$ Qualificações as quais muitas vezes eram também associadas às populações indígenas. OSÓRIO, 1990.

55 OSÓRIO, 1990

${ }^{56}$ OSÓRIO, 1990. A autora destaca, entretanto, que o Bando de José Marcelino de Figueiredo de 1773 foi o único documento nesse sentido por ela encontrado através de suas pesquisas.

57 Trata-se, na realidade, de um bando, como se pode perceber através da leitura do documento. Apesar disso, o governador refere-se a tal bando como "edital".
} 
auxiliares, de ordenanças "a pé e de Cavalo, e a todos os Estancieiros e moradores neste Continente", os quais não deviam consentir no abrigo aos "homens vagamundos", prendendoos e remetendo "os das Fronteiras e suas vizinhanças aos respectivos Comandantes delas, para por eles me serem enviados, e os dos mais Distritos à primeira Guarda Militar que encontrarem”. Ou seja, a distribuição de oficiais militares e sua explícita cadeia hierárquica visava organizar a relação entre a comunidade dos vassalos e as áreas por eles habitadas, incidindo numa territorialização de perfil militarizado, o qual tocava a ação da Justiça. Aos Comandantes de Fronteira cabia organizar frações da capitania, articulados ao governador. Conforme o cargo se mostrava funcional, voltava a ser mencionado nos documentos posteriores, dirigidos aos "Comandantes das Fronteiras, e mais lugares, aos Capitães dos Distritos e mais Oficiais de Infantaria, Dragões, Cavalaria Auxiliar e Ordenanças”.

A modificação concretizada através da instrução de 1769 possibilitou também que o território sob jurisdição do governador da capitania pudesse ser dividido a partir do início da década seguinte em três unidades territoriais, muito em virtude da organização militar da capitania. Duas dessas divisões estavam baseadas nas principais localidades da capitania à época: Viamão e Rio Pardo. A primeira era cabeça da capitania e sede da única Câmara, mas foi logo substituída por Porto Alegre, em 1773, sendo ambas localizadas no "centro" da capitania. Já Rio Pardo, sede da Fronteira de mesmo nome, estava localizada a sudoeste, na confluência dos rios Pardo e Jacuí. A Fronteira do Norte, por sua vez, estava baseada na fortificação de São José do Norte, principal ponto de defesa ao sul. Localizava-se em frente à vila de Rio Grande, a qual estava ocupada pelos espanhóis desde 1763. Esses dois locais eram separados apenas pelo desaguadouro da Lagoa dos Patos no oceano Atlântico, em cujo trecho as margens distavam em torno de $5 \mathrm{~km}$ uma da outra. Após a reconquista dessa vila em 1776, a Fronteira do Norte foi substituída - e absorvida - pela Fronteira do Rio Grande, sediando-se nesse núcleo populacional. A partir do início da década de 1770, portanto, a Fronteira do Rio Pardo e a Fronteira do Norte - e, após 1776, a Fronteira do Rio Grande - constituíram-se em unidades territoriais sob as ordens dos Comandantes de Fronteira. Viamão - e posteriormente Porto Alegre - ficou sob as ordens diretas dos governadores da capitania, constituindo a terceira parcela. Dessa forma, após algumas modificações devidas à reorganização do governo e à reincorporação da vila de Rio Grande durante a década de 1770, a divisão tripartite do território 
sob jurisdição desses governadores consolidou-se ao fim do referido decênio, sendo composta desde então por Porto Alegre, Fronteira do Rio Pardo e Fronteira do Rio Grande.

Considere-se que essas divisões eram também circunscrições militares ${ }^{58}$, as quais permitiam uma melhor organização das forças da capitania - e especialmente a defesa daquelas denominadas enquanto fronteiras. Além disso, tais unidades territoriais rapidamente passaram a conter diversos núcleos populacionais, fossem eles freguesias ou capelas, e igualmente seus distritos militares. No caso da Fronteira do Rio Pardo, já em 1780 ela abarcava as freguesias de Rio Pardo, Cachoeira e Santo Amaro. A Fronteira do Norte correspondia, muito provavelmente, apenas às freguesias do Estreito e de Mostardas. Posteriormente, a Fronteira do Rio Grande abarcou ambas e a própria freguesia de São Pedro do Rio Grande. No início da década de 1780, um novo Comandante de Fronteira foi designado pelo recém-empossado governador Sebastião Xavier da Veiga Cabral da Câmara para a Vacaria, no noroeste da capitania. Ao mesmo tempo, essa área passou a ser designada pelo mesmo governador como Fronteira da Vacaria, ficando seu comandante responsável pelos distritos dessa freguesia e de São Francisco de Paula de Cima da Serra. ${ }^{59}$ Ao que tudo indica, porém, essa Fronteira não constituiu uma divisão territorial da capitania, tendo feito parte da unidade sediada em Porto Alegre ao longo do século XVIII, muito provavelmente em virtude da proximidade em que estava da sede dela. E tal qual ocorrera com a Fronteira do Norte no final da década de 1770, certamente a Fronteira da Vacaria também veio a caducar, dessa vez em virtude da anexação definitiva dos territórios dos sete povos das missões orientais, a oeste da capitania, no ano de 1801. Esse episódio, juntamente com o surgimento de novos núcleos populacionais e com a multiplicação de vilas a partir de 1809 , acarretou no início da modificação da configuração desenhada neste parágrafo e no anterior, a qual foi válida até o final do século XVIII.

\section{CONSIDERACÕES FINAIS}

$\mathrm{Na}$ instrução de 1769, o então governador José Marcelino mencionou as "duas Fronteiras desta Província”. Essa utilização tem dupla implicação: a primeira é conceber as

\footnotetext{
${ }^{58}$ COMISSOLI, VIANNA, 2017.

${ }^{59}$ BIBLIOTECA NACIONAL. Coleção Castelo Melhor, 09, 4, 010. Ofícios entre os governadores e responsáveis pelo governo do Rio Gra nde e o vice-rei do Estado do Brasil, Luís de Vasconcelos e Souza. 1781
} 
fronteiras como partes de um todo, qual seja, a Província, ou capitania sob sua jurisdição; a segunda é que os territórios ao norte da capitania, os quais também eram limítrofes, não foram compreendidos naquele momento enquanto "fronteiras", o que pode também estar demonstrando que a frontalidade com os castelhanos - ou mesmo a circunstância de guerra viva - era preponderante na qualificação de determinados territórios enquanto fronteira. De certa forma, essas eram as condições em que uma parte dos distritos setentrionais da capitania se encontrava no início da década de 1780 e, talvez não por acaso, o então governador Sebastião Xavier da Veiga Cabral da Câmara utilizou dessa mesma retórica para qualificar esses territórios enquanto Fronteira da Vacaria, designando também um Comandante de Fronteira para essa área.

A solução apresentada por José Marcelino de Figueiredo em 1769 respeitava dois níveis governativos. No primeiro, ele seria o responsável, enquanto governador, pela administração da capitania ou província do Rio Grande de São Pedro. No segundo nível e devidamente subordinados, atuariam dois Comandantes de Fronteira, que deveriam ser indicados dentre os mais capazes oficiais militares das tropas pagas. A função destes militares era de organizar o território, evitando a movimentação constante do governador e possibilitando a mais rápida resposta aos desafios impostos pelos espanhóis e pela repressão aos criminosos.

A opção de Figueiredo foi uma resposta pontual a um problema específico: a melhor condução da guerra contra os espanhóis. Contudo, a situação de fronteira perdurou e novos confrontos seguiram-se. Nos anos de 1801, 1804, 1811 e 1812, de 1816 a 1820 e de 1825 a 1828, outros combates e campanhas militares tiveram lugar, motivados por conjunturas específicas, mas com o elemento comum de dotarem as relações de fronteira de animosidade em seu referencial político. Nos anos em que ações militares não foram registradas, patrulhas e espiões realizavam ações de inteligência, reportando-se justamente aos Comandantes das Fronteiras de Rio Pardo e de Rio Grande. O avanço português e a incorporação de novos territórios modificaram os arranjos de fronteira, gerando novos pontos de contato e novas denominações: Fronteira das Missões, Fronteira do Jaguarão, dentre outras. Contudo, o cargo permaneceu.

A longevidade do ajuste regional se justifica por ter rearranjado a tradição militar ibérica. A exemplo dos capitães-mores de Ordenanças e dos mestres de campo dos Terços 
Auxiliares, o Comandante de Fronteira fundia autoridades emanadas pelo poder central e local, sendo este o principal âmbito de atuação de todos esses agentes. Não obstante, dentre os Comandantes de Fronteira a ênfase se deu entre oficiais das tropas regulares de primeira linha, diretamente escolhidos pelo governador, o que potencializava sua atuação enquanto agentes imperiais. Privilegiou-se uma situação que possibilitasse o recrutamento de soldados e o controle da população, sem espaço para concorrência com o poder régio - e a hierarquia militar, à qual os oficiais das tropas de linha estavam mais habituados, certamente teve seu peso nesse arranjo. Contudo, o sistema perdurou e adaptou-se. Alguns anos após o surgimento dos Comandantes de Fronteira, novas gerações das famílias sul rio-grandenses estavam disponíveis nas tropas militares e passaram a oferecer uma opção consistente para ocupar os postos de comandantes: conheciam o terreno, conheciam os homens a comandar, eram hábeis cavaleiros e contavam prestígio na região, o que oferecia maior respaldo ao seu comando - e, por extensão, à manutenção daqueles territórios enquanto possessões da Coroa lusa ou enquanto parcelas do Império do Brasil, conforme a conjuntura. Resulta daí que viessem a novamente se fundir as legitimidades oficiais e personalistas. A prática perdurou para além da emancipação política brasileira e os postos de Comandantes de Fronteira na então Província de São Pedro do Rio Grande sobreviveram à criação da Guarda Nacional, em 1831, existindo ao menos até o início da Guerra dos Farrapos (1835-1845). Se sua longevidade é um indício do êxito que o cargo teve durante o período colonial enquanto solução para a organização militar, administrativa e territorial dessa parcela das possessões lusas, isso o torna particularmente atraente para a continuidade das investigações.

Um roteiro para futuras investigações deve considerar a atuação dos comandantes militares, especialmente das tropas regulares, na organização da sociedade. Como argumentamos, os oficiais de alta patente não se responsabilizavam somente pelos recrutados e soldados, mas por frações consideráveis da população que habitavam suas repartições militares: as fronteiras de Rio Grande e de Rio Pardo, no caso dos comandantes, e os distritos, no caso dos demais oficiais. Portanto, a atuação de comandantes militares - não apenas os responsáveis por fronteiras - pode e deve ser testada para diferentes territórios do império português. Assim como os instrumentos de justiça e as Câmaras, eles atuaram como agentes da territorialização dos poderes e ao considerar a relação entre os distintos ramos poderemos entender as oscilações 
entre sua maior presença ou ausência, por exemplo, a existência de capitanias com poucas ou uma única vila.

Paralelamente, e tendo em vista que as soluções governativas encontradas pelos agentes das coroas ibéricas se caracterizavam enquanto experiência coletiva, é oportuno destacar que aquelas observadas neste trabalho passam a integrar essa mesma experiência. Embora haja uma modificação na caracterização dos poderes existentes em âmbito local, tais poderes continuam sendo necessários para a administração dos territórios das possessões ibéricas no continente americano - e a existência dos Comandantes de Fronteira o demonstra. Dessa forma, se as opções governativas aqui observadas apontam para uma modificação nas políticas para o governo dos territórios no âmbito local em direção a uma maior racionalização em termos administrativos, talvez seja interessante questionar o quanto soluções encontradas nesse mesmo sentido influenciaram-se mutuamente - seja enquanto experiência coletiva lusa ou ibérica - e como se relacionaram com os poderes estabelecidos, se for o caso. Sendo assim, entendemos que observar processos semelhantes - ou distintos - em diferentes contextos locais possa ser bastante profícuo para complexificar a compreensão acerca dos construtos imperiais ibéricos e, igualmente, das soluções governativas adotadas em função da dissolução desses mesmos construtos no continente americano. Resulta dessa perspectiva, portanto, considerar o alto grau de pragmatismo do império português, capaz de se transformar não apenas a partir de seus centros de poder mais destacados, mas igualmente através de soluções de nível local.

\section{REFERÊNCIAS}

\section{Fontes}

ARQUIVO HISTÓRICO DO RIO GRANDE DO SUL. Códices de Registro Geral da Real Fazenda do Rio Grande de São Pedro, códice F1243. Registro de uma instrução e ordens para os Comandantes das Fronteiras que devem observar, passada pelo Sr. Coronel Governador José Marcelino de Figueiredo. Fortes de São José do Norte, 15 de junho de 1769, fl. 197-201v.

Códices de Registro Geral da Real Fazenda do Rio Grande de São Pedro, códice F1242. Registro das Instruções que o Sr. Coronel Governador José Custódio de Sá e Faria deixou ao Tenente-Coronel Francisco Barreto Pereira Pinto, Comandante do quartel do Rio Pardo. Fortaleza de Jesus Maria José do Rio Pardo, 10 de setembro de 1764, fl. 205v-208v. 
Fundo Fazenda, códice F1244, fls. 27v. e 28, Registro de uma portaria que o Tenentecoronel Governador para se registrar o capítulo de uma carta do Ilmo. E Exmo. Sr. Marquês Vice-rei do Estado sobre as espias que são necessárias, 19/05/1772.

ARQUIVO HISTÓRICO ULTRAMARINO, cx. 3, doc. 252. Ofício do Brigadeiro Rafael Pinto Bandeira a Martinho de Melo e Castro, 29 de fevereiro de 1791.

ARQUIVO NACIONAL. Códice 69, Vice-reinado. Registro de correspondência do vicereinado para a Corte. Conde de Azambuja a Francisco Xavier de Mendonça Furtado, 09 de março de 1769. fl. 36v-38.

Códice 104. Volume 13. Francisco Barreto Pereira Pinto ao Ten. Cel. Patrício José Correa da Câmara. Guarda de São Pedro, 22 de julho de 1801. fl. 180 apud OSÓRIO, 2007, Op. Cit., p. 169.

BIBLIOTECA NACIONAL. Coleção Castelo Melhor, 09, 4, 010. Ofícios entre os governadores e responsáveis pelo governo do Rio Grande e o vice-rei do Estado do Brasil, Luís de Vasconcelos e Souza. 1781.

. Coleção Martins, 13, 04, 02. Correspondência do Marquês de Lavradio com o Marechal João Henrique de Böhn. 1774-1775. 3 de dezembro de 1774, fl. 46-52.

L. Coleção Martins, 13, 06, 06. Correspondência de José Marcelino de Figueiredo com o General João Henriques Bohm. 1774-1776, fl. 444-445.

CARTA do Governador José Marcelino de Figueiredo para o Vice-rei, Marquês do Lavradio (24 de março de 1779). Revista do Museu e Archivo Público do Rio Grande do Sul, n. 23, jun/1930, p. 405.

CARTAS do Governador José Marcelino de Figueiredo para o Vice-rei, Marquês do Lavradio (1776). Revista do Instituto Histórico e Geográfico do RGS, ano 93, n. 147, 2013, p. 183.

CARTAS do Governador José Marcelino de Figueiredo para o Vice-rei, Marquês do Lavradio (1773). Revista do Instituto Histórico e Geográfico do RGS, ano 90, n. 144, 2010, p. 194.

CARTAS do Governador José Marcelino de Figueiredo para o Vice-rei, Marquês do Lavradio (1773). Revista do Instituto Histórico e Geográfico do RGS, ano 90, n. 144, 2010, p. 186.

REGULAMENTO para a conservação dos animais das fazendas e estâncias dos particulares. Transcrito em SANTOS, Corcino Medeiros dos. Economia e sociedade do Rio Grande do Sul: século XVIII. São Paulo: Ed. Nacional; Brasília: INL, Fundação Nacional Pró-Memória, 1984, p. 193-202.

Obras Gerais

ACRUCHE, Hevelly Ferreira. A fronteira e as gentes. Diplomacia, lealdades e soberanias no extremo sul da América Ibérica (1750-1830). Curitiba: Prismas, 2019. 
ALDEN, Dauril. Royal Government in Colonial Brazil. Berkeley e Los Angeles: University of California Press, 1968.

ANDERSON, Benedict. Nação e consciência nacional. São Paulo: Editora Ática, 1989.

ARRIAGA RODRÍGUEZ, Juan Carlos. El largo proceso histórico de partición territorial: las fronteras em América Latina y el Caribe, siglos XVI al XXI. México: Bonilla Artigas Editores/Universidad de Quintana Roo, 2012.

BICALHO, Maria Fernanda Baptista. Sertão de Estrelas. A delimitação das latitudes e das fronteiras na América Portuguesa. Varia História, Belo Horizonte, v. 21, p. 73-85, 1999.

CARDIM, Pedro; HESPANHA, António Manuel. A estrutura territorial das monarquias ibéricas. In: XAVIER, Ângela Barreto et al. (Org.). Monarquias ibéricas em perspectiva comparada. Lisboa: ICS - Imprensa de Ciências Sociais, 2018.

CHERUBINI, Maria Belén. Uma frontera ¿imposible?: los conflictos hispanoportugueses em el sur de América y la expedición a Rio Grande de San Pedro (1773). Fronteras de La Historia. 26(2), 2021, pp. 238-262. https://doi.org/10.22380/20274688.1409

COMISSOLI, Adriano. Bombeiros, espias e vaqueanos: agentes da comunicação política no sul da América portuguesa (Rio Grande de São Pedro, séc. XVIII-XIX). Revista de Índias. Volume LXXVIII, Número 272, 2018, p. 113-146.

COMISSOLI, Adriano. Os "homens bons" e a Câmara municipal de Porto Alegre (17671808). Porto Alegre: Gráfica da UFRGS, 2008.

COMISSOLI, Adriano; GIL, Tiago Luís. Camaristas e potentados no extremo da Conquista, Rio Grande de São Pedro, 1779-1810. In. FRAGOSO, João; SAMPAIO, Antonio Carlos Jucá de (Org.). Monarquia pluricontinental e a governança da terra no ultramar atlântico luso: séculos XVI-XVIII. Rio de Janeiro: Mauad X, 2012.

COMISSOLI, Adriano; VIANNA, Clarissa Prestes Medeiros. Governadores e generais: comunicação, inteligência e defesa no Rio Grande de São Pedro português. Revista Navigator, v. 13, p. 11-24, 2017.

CORI, Gabriel H. El Teniente de Gobernador Joaquín Maciel y la administración de las Temporalidades. Santa Fe, 1776-1771. Historia Regional, Sección Historia. ISP No 3, Año XIX, No 24, 2006, p. 133-150.

COSTA, Fernando Dores. Insubmissão. Lisboa: Imprensa de Ciências Sociais, 2010.

CRUZ, Miguel Dantas da. A militarização do território no Brasil Meridional (c.1766-1800). In: MOTA, Márcia; SERRÃO, José Vicente; MACHADO, Marina (Org.) Em terras lusas: conflitos e fronteiras no Império Português. Vinhedo: Editora Horizonte, 2013. 
CUNHA, Mafalda Soares da; NUNES, António Castro. Territorialização e poder na América portuguesa. A criação de comarcas, séculos XV-XVIII. Tempo, v. 22, n. 39, p. 01-30, jan-abr. 2016.

DIAS, Gabriela Duque. "Uma muy honrosa" patente militar: os mestres de campo nas Minas Setecentistas (1709-1777). Dissertação (Mestrado em História), Universidade Federal de Juiz de Fora, 2013.

DOUGNAC RODRÍGUEZ, Antonio. Gobierno, justicia, guerra y hacienda. Autoridades radicadas em Indias. In: Manual de História del derecho indiano. México: McGraw-Hill, 1998.

FIGUEIREDO, Luciano Raposo de Almeida. O Império em Apuros: Notas para o Estudo das Alterações Ultramarinas e das Práticas Políticas no Império Colonial Português Séculos XVII e XVIII. In. FURTADO, Júnia Ferreira (Org.). Diálogos Oceânicos. Belo Horizonte: Editora UFMG, 2001.

GIL, Tiago. Infiéis Transgressores: elites e contrabandistas nas fronteiras do Rio Grande e do Rio Pardo (1760-1810). Rio de Janeiro: Arquivo Nacional, 2007.

Coisas do caminho: tropeiros e seus negócios do Viamão à Sorocaba (17801810). 2009. 371f. Tese (Doutorado em História Social), Universidade Federal do Rio de Janeiro, Rio de Janeiro, 2009.

GOLIN, Tau. A fronteira (Volume 3): 1763-1778 - História da brava gente e miseráveis tropas de mar e terra que conquistaram o Brasil meridional. Passo Fundo: Méritos, 2015.

KÜHN, Fábio. Um governador em apuros. A trajetória administrativa de José Marcelino de Figueiredo (Rio Grande de São Pedro, 1769-1780). In. DORÉ, Andréa (Org.). Temas setecentistas: governos e populações no Império português. Curitiba: UFPR, 2008, p. 169-180.

MIRANDA, Márcia Eckert. Continente de São Pedro: a administração pública no período colonial. Porto Alegre: Assembléia Legislativa do Estado do RS/Ministério Público do Estado do RS/CORAG, 2000.

NEUMANN, Eduardo. Fronteira e identidade: confrontos luso-guarani na Banda Oriental, 1680-1757. Revista Complutense de Historia de América, n. 26, 2000. Pp. 73-92.

OSÓRIO, Helen. Apropriação da terra no Rio Grande de São Pedro e a formação do espaço platino. 1990. Dissertação (Mestrado em História) - Programa de Pós-Graduação em História, UFRGS, Porto Alegre, 1990.

O império português no sul da América: estancieiros, lavradores e comerciantes. Porto Alegre: Editora da UFRGS, 2007.

PICCOLI, Andréia Aparecida. Julgar a cada um o que é seu: justiça e criminosos nos domínios portugueses da Fronteira Platina (1777ca.-1810ca.). Dissertação (Mestrado em História), Universidade de Passo Fundo, 2019. 
QUINTERO, Gilberto R. Gobernadores y tenientes de gobernador en la província de Venezuela. De los Welser a Juan de Villegas (1528-1553). Revista Mañongo, nº17, 2001 pp. 289-300.

RIBEIRO, Mônica. "Razão de Estado” e Administração: Gomes Freire de Andrada no Rio de Janeiro, 1733-1748. Dissertação (Mestrado em História), Universidade Federal Fluminense, Niterói, 2006.

SALGADO, Graça (Coord.). Fiscais e Meirinhos, A Administração no Brasil colonial. Rio de Janeiro: Nova Fronteira, 1986.

SANTOS, Corcino Medeiros dos. Economia e sociedade do Rio Grande do Sul: século XVIII. São Paulo: Ed. Nacional; Brasília: INL, Fundação Nacional Pró-Memória, 1984.

Recebido em: 05/08/2021 - Aprovado em: 04/10/2021 